\title{
CHANGES OF PHYSICALLY-CHEMICAL PARAMETERS OF 'NANTE' CARROT HYBRIDS DURING STORAGE IN TRADITIONAL CONDITIONS
}

\author{
Ingrīda Augšpole, Tatjana Rakčejeva, and IIze Grāmatiṇa \\ Department of Food Technology, Latvia University of Agriculture, Lielā iela 2, Jelgava LV 3001, LATVIA \\ ingrida.augspole@inbox.lv
}

Communicated by Dalija Seglina

\begin{abstract}
The current research focuses on changes of physically-chemical parameters of 'Nante' carrot hybrids during storage in traditional conditions. Quality parameters during carrot storage for six months at temperature $8 \pm 2{ }^{\circ} \mathrm{C}$ and relative air humidity $85 \pm 1 \%$ were evaluated using standard methods: soluble solids (digital refractometer), dietary fibre (AOAC 985.29), ascorbic acid (iodometric) and firmness (TA.XT.plus Texture Analyser). Before storage, hybrids 'Nante/Berlikum', 'Nante/Maestro' and 'Nante/Bolero' had higher soluble solid content: 1.6 times higher comparing with hybrid 'Nante/Forto' and 1.2 times higher compared with hybrid 'Nante/Champion'. These hybrids also had higher ascorbic acid content: 2.0 times higher than in 'Nante/Forto' and 'Nante/Champion'. Significant differences were not found in dietary fibre content and firmness of non-stored carrots. Substantial differences were observed in soluble solid content in the hybrid 'Nante/Berlikum' during six-month storage - the content decreased 2.0 times. However, nonsignificant decrease of soluble solids content decreases was found for the hybrid 'Nante/Forto'. Changes in hybrid firmness and dietary fibre amount were not significant during storage for four months. Ascorbic acid content of the carrot hybrids during storage decreased by 3.4 times.
\end{abstract}

Key words: carrot, soluble solids, dietary fibre, ascorbic acid, firmness, storage.

\section{INTRODUCTION}

Carrot is a globally important vegetable crop that is a source of important nutritional compounds (including pro-vitamin A) through their carotenoid content, and adds flavour and texture to many diets across the world (Rakcejeva et al., 2012). Vegetables are an important part of our diet. They provide not only the major dietary fibre component of our food, but also a range of micronutrients, including minerals, vitamins and antioxidant compounds (Rashidi, 2011; Rakcejeva et al., 2012; Singh et al., 2012). It is known that growth conditions and management practices affect the concentrations of these compounds, and thus also nutritional value and taste (Singh et al., 2012). As consumers move toward functional foods with specific health effects, scientists and food manufacturers have also taken an interest in the potential of the antioxidant constituents of carrots to maintain health (Yen et al., 2008). Considering that carrot is one of the primary vegetables in many countries and can adequately supply most, if not all, of the vitamin A daily requirement of humans (from a $100 \mathrm{~g}$ serving of raw carrot (Singh et al., 2012)), it is important to enhance the nutritional status of carrot when possible.

Carrots are an important source of vitamin $\mathrm{C}$ in the human diet, but the content can decrease during storage (Matejkova and Petrikova, 2010). Compared to other horticultural crops, it has been reported that New Zealand-grown carrots have higher vitamin $\mathrm{C}$ content than New Zealand-grown grapes, nectarines, pears and plums (Leong, 2012). Carrots can be consumed fresh or cooked, either alone or with other vegetables, in the preparation of soups, stews, curries and pies. Fresh grated roots are used in salads and tender roots are pickled (Soria et al., 2009; Rashidi, 2011). Ascorbic acid (vitamin C) is used extensively in the food industry, not only for its nutritional value but also for its many functional contributions to product quality. Leong in 2012 reported that the human body is unable to synthesise vitamin $\mathrm{C}$ due to the lack of enzyme L-gulonolactone oxidase. Vitamin $\mathrm{C}$ helps to prevent scurvy, reduce the risk of cancers and cardiovascular diseases and enhance the absorption of iron to prevent anaemia. In plants, the active form of vitamin C, i.e. L-ascorbic acid (L-AA) acts as an enzyme cofactor, electron donor or acceptor in the proton electron transport system and as a substrate for oxalate and tartrate biosynthesis. The stability of vitamin $\mathrm{C}$ in carrots can be influenced by factors from pre-harvest (including cultivars and environment conditions) to harvest and post-harvest handling (Leong, 2012). Some scientists believe that vitamin $\mathrm{C}$ acts as an antioxidant in plants and that its levels are sensitive to a variety of environmental or stress factors, for 
example, light, temperature, salt and drought, atmospheric pollutants, metals or herbicides (Singh et al., 2012). Fresh vegetables have a short durability, and are exposed to conditions that destroy their superior quality in a short period of time, before cooking and consumption (Giannakourou and Taoukis, 2003). Cultivar and soil climatic conditions affect the concentrations of compounds in carrot roots, which are important for both human nutrition and taste (Smoleń and Sady, 2009).

Fruits and vegetables are good sources of dietary fibre (DF). $\mathrm{DF}$ is a group of food components, which are resistant to hydrolysis by human digestive enzymes. The health benefits of dietary fibre have led to increased consumption of fibrerich products (Chantaro et al., 2008). Fibres are an integral part of the foodstuffs we consume daily; the main sources in which these fibres occur are plants, vegetables, cereal grains, woody plants, fruits, legumes, leguminous plants, etc. Based on their simulated intestinal solubility, dietary fibres are either classified as insoluble or soluble fibres. Insoluble fibres include lignin, cellulose, and hemicelluloses; soluble fibres include pectins, beta-glucans, galactomanan gums, and a large range of non-digestible oligosaccharides including inulin (Rodriguez et al., 2006; Chantaro et al., 2008; Slavin, 2008). At present, there are still many aspects about DF properties and functions that remain unclear. Botanists define fibre as a part of the plant organs, chemists as a group of chemical compounds, consumers as a substance with beneficial effects on human health, and for the dietetic and chemical industries DF is a subject of marketing (Rodriguez et al., 2006). DF is part of a plant matrix which is largely intact. Non-digestible plant carbohydrates in foods are usually a mixture of polysaccharides that are integral components of the plant cell wall or intercellular structure (Slavin, 2008). Post-harvest storage of fresh fruits and vegetables needs to be such that the organoleptic (colour, texture and flavour) and nutritional properties of the final product are maintained in optimal conditions. Changes in fibre quantity and quality depend to a great extent on storage conditions (Rodriguez et al., 2006). DF concentrates obtained after dehydration of fresh fruit and vegetables can be used in the food industry as functional ingredients with excellent results. DF from cereals is more frequently used than fibre from fruit or vegetables. However, fruit and vegetable fibre has better quality due to it's higher soluble DF content, better water and oil holding capacities and better colonic fermentability, as well as lower phytic acid contents and energy (Eim at al., 2008). Some scientists believe that DF acts as a protective agent against cardiovascular diseases, diverticulosis, constipation, irritable colon, colon cancer and diabetes (Chau et al., 2004; Eim at al., 2008; Slavin, 2008; Brownlee, 2011). Five specific methods of DF analysis and the certified values in dried carrots used as European Reference Material o(riginally certified as BCR515) are shown in the Table 1 (Emons, 2011).

Soluble solids in carrot roots consist mostly of soluble sugars, and therefore affect sensory sweetness impression (Gajewski et al., 2010). Soluble solid content has a pro-
Table 1

CONTENT OF DIETARY FIBRE IN DRIED CARROTS (Emons, 2011)

\begin{tabular}{c|c|l}
\hline Nr. & $\begin{array}{c}\text { Mass fraction } \\
\mathrm{g} \cdot \mathrm{kg}^{-1(*)}\end{array}$ & \multicolumn{1}{c}{ Dietary fibre according to } \\
\hline 1 & 311 & AOAC, 1990, 985.29 \\
2 & 271 & Englyst by GC \\
3 & 298 & Uppsala 994.13 \\
4 & 295 & AOAC, 1992, MES-TRIS, 991.43 \\
5 & 252 & Englyst by Colorimetry \\
\hline
\end{tabular}

(*) The values are expressed on dry mass basis.

found influence on the storage period length, mechanical properties and quality characteristics of fruits and vegetables (Rashidi, 2011). The sensory qualities of fresh vegetable such as carrot depend on their texture, which correlate well with the freshness of the produce. The cutting test is one of the common methods for determining textural changes in food products. It is generally applied with maximal cutting force as an attribute of the studied material quality (Rawson et al., 2012).

Texture is a major quality characteristic of fruits and vegetables. The notion of "texture engineering" has been introduced in the context of texture optimisation of processed fruits and vegetables (Roeck et al., 2010). Many earlier researchers employed instrumental texture measurement (also known as the hardness) to quantify product quality. Hardness is often defined as the peak force corresponding to the first compression of the sample. Product firmness and tissue elasticity are provided by pectic substances. Pectin is a major component present in middle lamella. Solubilisation of pectic compounds in the middle lamella results in intercellular weakening and cell separation leading to texture degradation. Under controlled conditions, the action of endogenous pectinases, such as pectinmethylesterase (PME) and polygalacturonase (PG), on the pectin is highly correlated with texture degradation of fruits and vegetables (Rastogi et al., 2008). Traditionally the harvesting of carrots in Latvia starts from middle of summer, however, the main harvest occurs in autumn. Worldwide carrots can have purplish, yellow, green, white and black colour, but in Latvia mainly bright orange. The main carrot variety is 'Nante' and its hybrids (Rakcejeva et al., 2012). Unfortunately, the brittleness that accompanies crisp texture tends to have a negative impact on the "durability" of carrots in mechanical harvesting and washing (Prohens et al., 2007).

The aim of the study was to determine changes of physically-chemical parameters of 'Nante' carrot hybrids during storage in traditional conditions.

\section{MATERIALS AND METHODS}

The study was carried out in the Department of Food Technology at the Latvia University of Agriculture. Carrots (Daucus carota L.) grown in Latvia and harvested in Zemgale region from four farms in the first part of October 
2011 were immediately used for experiments. Serotinous 'Nante' carrot hybrids 'Nante/Berlikum', 'Nante/Maestro', 'Nante/Forto', 'Nante/Bolero' and 'Nante/Champion' were used. Quality parameters of carrots were determined during six-month storage at temperature $+8 \pm 2{ }^{\circ} \mathrm{C}$ and relative air humidity $85 \pm 1 \%$ using standard methods. Carrots were sampled in October, December 2011 and February, April 2012 (sampling interval of two months). Meteorological data were obtained from the Latvian Environment, Geology and Meteorology Centre. Meteorological conditions of 2011 where characteristic with relatively high temperatures in the first two months of summer of 2011. June and July months were also warm, with average air temperature in June $+24.5{ }^{\circ} \mathrm{C}$ and maximum air temperature $+32.3{ }^{\circ} \mathrm{C}$. In summer 2011, average rainfall was $274 \mathrm{~mm}$, i.e. close to optimal precipitation. Autumn 2011 in Latvia was warm and relatively dry. All autumn months were warmer and drier than normal. The autumn temperature was 1.9 degrees above normal. Autumn precipitation was $67 \%$ of the average level.

Ascorbic acid. Ascorbic acid content was determined by titration with $0.05 \mathrm{M}$ iodine solution (Moor et al., 2005). Samples of $25 \mathrm{~g}$ carrot were mixed with $100 \mathrm{~mL} \cdot 6 \mathrm{~g} \cdot 100$ $\mathrm{g}^{-1}$ oxalic acid solution and homogenised for $60 \mathrm{~s}$, and then the sample was filtered. $10.0 \mathrm{ml}$ of the filtrate and $2.0 \mathrm{ml}$. $1 \mathrm{~g} 100 \mathrm{~g}^{-1}$ starch solution was titrated until the endpoint was reached (first sign of blue colour that persisted after $30 \mathrm{~s}$ ). The titration was repeated in triplicate for each sample. The ascorbic acid content was calculated as:

$x=\frac{V_{\text {sample }} \times 5000}{V_{s \tan \text { dard }} \times g}$, where

$\mathrm{V}_{\text {sample }}$ - iodine amount for sample titration, $\mathrm{ml}$;

$\mathrm{V}_{\text {standard }}$ - iodine amount for vitamin $\mathrm{C}$ standard solution titration, ml;

$\mathrm{g}$ - sample weight, $\mathrm{g}$.

Total dietary fibre. The total dietary fibre in samples was determined according to the AOAC approved method No. 985.29. The experiments were carried out by using a FOSS Analytical Fibertec E 1023 system with enzymatic processing by incubation in a thermostatic shaking water bath; residue filtration was conducted using a Filtration Module, and protein determination by Kjeldahl (Method 46-12, 1995) nitrogen equipment. The analyses were performed in three repetitions. The samples were defatted and dried with a particle size less than $0.5 \mathrm{~mm}$. Then each sample was enzymatically digested with $\alpha$-amylase incubation at $+100{ }^{\circ} \mathrm{C}$, and with protease and amyloglucosidase incubation at $+60{ }^{\circ} \mathrm{C}$. After digestion, the total fibre content was precipitated by adding $95 \mathrm{~g} \cdot 100 \mathrm{~g}^{-1}$ ethanol. The solution was then filtered and fibre was collected, dried and weighed. The protein and ash content were determined for correction of fibre content (Prosky, 1990).

Soluble solids content (SSC). The soluble solid content ( ${ }^{\mathrm{O}}$ Brix) was determined at temperature $+20 \pm 2{ }^{\circ} \mathrm{C}$ with a digital refractometer (deviation of measuring instrument $\pm 0.1 \%$ ) by standard method ISO 2173:2003.

Firmness. A structure analyser "TA.XT.plus texture Analyser" (Stable Micro Systems Ltd., Surrey, UK) and measuring probe HDP/BSK (blade set with knife, supplied with the Texture Analyser) were used for firmness determination. The system was equipped with a compression cell of $50 \mathrm{~kg}$ and software Texture Exponent 32. Firmness was measured as the maximum penetration force $(\mathrm{N})$ reached during tissue breakage. The measuring parameters were: pre-test speed $\cdot 2 \mathrm{~mm} \mathrm{~s}^{-1}$; test speed $2 \cdot \mathrm{mm} \mathrm{s}^{-1}$; post-test speed $10 \mathrm{~mm} \cdot \mathrm{s}^{-1}$; penetrating distance $23 \mathrm{~mm}$ into the carrot. The measurement was triggered automatically at 0.04903 N (Rakcejeva et al., 2012).

Statistical analysis. Data were expressed as mean \pm standard deviation; for mathematical data processing the value of $P<0.05$ was regarded as statistically significant. One-way analysis of variance (ANOVA) was used to determine the significance of differences. In cases of statistically significant differences, homogeneous groups were determined by Tukey's multiple comparison test at the level of confidence $\alpha=0.05$. The statistical analyses were performed using Microsoft Excel 2007.

\section{RESULTS}

Vitamin C. Vitamin C content $(P<0.05)$ (Fig. 1) significantly differed between fresh carrot hybrids. The highest vitamin C contents occurred in hybrids 'Nante/Maestro',

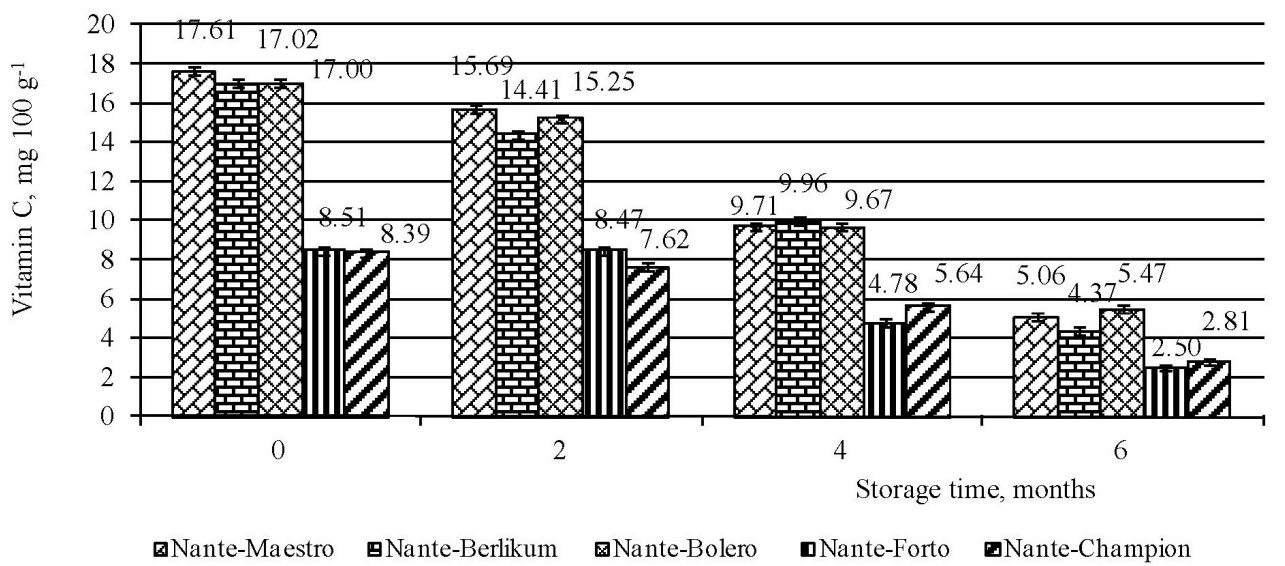

Fig. 1. Vitamin $\mathrm{C}$ content in variety 'Nante' carrot hybrids during storage. 
'Nante/Berlikum' and 'Nante/Bolero' (17.61 \pm 0.17, $17.02 \pm$ 0.01 and $17.00 \pm 0.01 \mathrm{mg} 100 \mathrm{~g}^{-1}$, respectively), which were significantly higher $(P<0.05)$ than in hybrids 'Nante/Forto' and 'Nante/Champion' $(8.51 \pm 0.01$ and $8.39 \pm$ $0.17 \mathrm{mg} \cdot 100 \mathrm{~g}^{-1}$, respectively). Vitamin C decreased significantly during carrot storage. After two-month storage, the decrease in ascorbic acid content was not significant $(P<$ 0.05): $~ 1.1$ times compared with initial $\mathrm{C}$ vitamin content. However, during carrot storage for four mounts, vitamin $\mathrm{C}$ content decreased by $\sim 1.7$ times, and after six-month storage by up to 3.3 times, particularly in hybrid 'Nante/ Berlikum' - 3.9 times less comparing with vitamin content in fresh carrots. These changes mainly could be explained by physically-chemical reactions in carrots during storage.

Total dietary fibre. It was found that the content of total dietary fibre in 'Nante' hybrid carrots ranged from $25.78 \pm$ 1.54 to $34.25 \pm 5.79 \mathrm{~g} \cdot 100 \mathrm{~g}^{-1}$. Higher total dietary fibre content was observed in non-stored hybrids 'Nante/Bolero', 'Nante/Maestro' and 'Nante/Berlikum': $34.25 \pm 5.79,29.80$

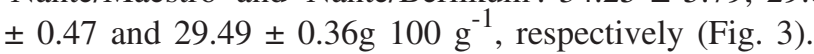

Soluble solids content and firmness. The soluble solid content (SSC) in fresh carrot hybrids ${ }^{\circ}$ Brix (Fig. 3) was within the range from $10.30 \%$ in 'Nante/Maestro' to $6.1 \%$ in 'Nante/Forto'. Soluble solid content was similar in 'Nante/Maestro', 'Nante/Bolero' and 'Nante/Berlikum': 10.30 $\pm 0.09 \%, 9.97 \pm 0.08 \%$ and $9.70 \pm 0.09 \%$, respectively. The lowest soluble solid content was observed in fresh carrots hybrids 'Nante/Champion' and 'Nante/Forto' (8.16 $\pm 0.18 \%$ and $6.11 \pm 0.07 \%$, respectively).
FIRMNESS (N) OF CARROT BEFORE AND AFTER STORAGE

\begin{tabular}{l|c|c|c}
\hline \multirow{2}{*}{ Carrot hybrids } & Before storage & $\begin{array}{c}\text { After six-month } \\
\text { storage }\end{array}$ & Whole period \\
\cline { 2 - 4 } & average $\pm \mathrm{SD}$ & average $\pm \mathrm{SD}$ & $\mathrm{X}_{\min }-\mathrm{X}_{\max }$ \\
\hline Nante/Bolero & $95.09 \pm 21.01$ & $100.41 \pm 7.50$ & $72.76-112.17$ \\
Nante/Maestro & $103.98 \pm 16.19$ & $87.99 \pm 9.03$ & $67.24-105.43$ \\
Nante/Berlikum & $82.24 \pm 14.78$ & $95.65 \pm 9.59$ & $53.62-109.96$ \\
Nante/Forto & $81.28 \pm 14.54$ & $114.47 \pm 9.91$ & $81.46-126.56$ \\
Nante/Champion & $82.93 \pm 15.08$ & $71.74 \pm 5.28$ & $62.08-95.11$ \\
Total & 89.70 & 94.05 & $67.43-109.85$
\end{tabular}

The firmness of carrot hybrids before and after storage is summarized in Table 2. Samples of 'Nante/Bolero', 'Nante/Berlikum' and 'Nante/Forto' required higher force for cutting than fresh carrot samples. During storage, 1.05 times higher cutting force needed to be applied than for fresh carrots. This was expected, as carrots contain about $90 \%$ water, which gives rigidity to the texture. Significant differences $(P<0.05)$ during the whole period of storage in firmness of carrot hybrids were found.

\section{DISCUSSION}

The retention of vitamin $\mathrm{C}$ is often used as an estimation of the overall nutritional quality of vegetables (GamboaSantos et al., 2012), as it is by far the least stable nutrient; it is highly sensitive to oxidation and leaching into water-soluble media during storage. It begins to degrade immediately

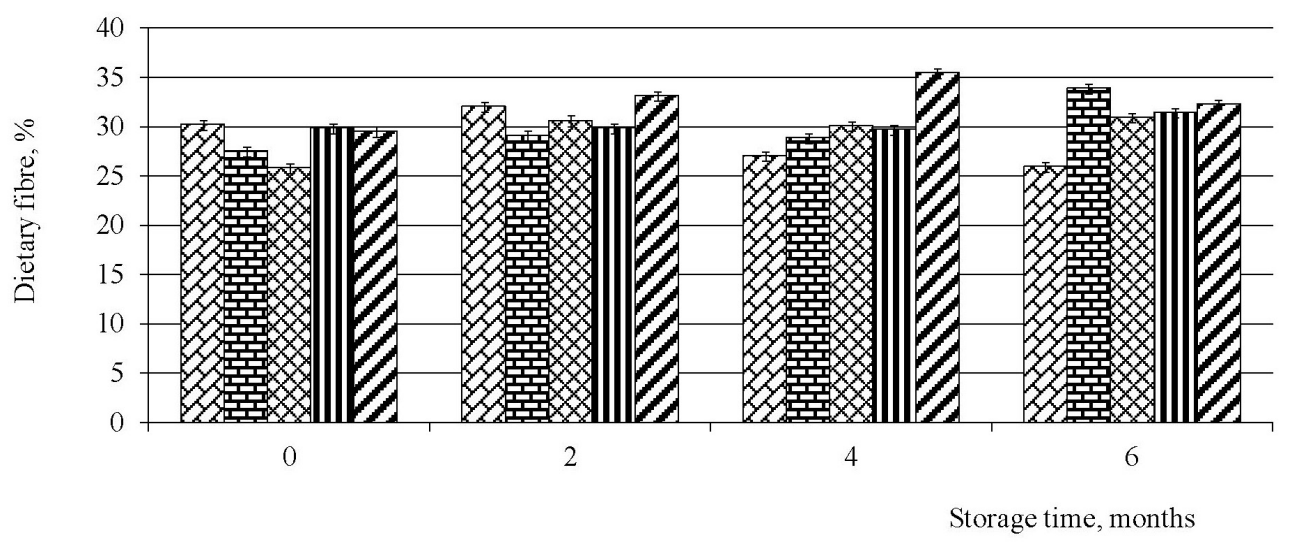

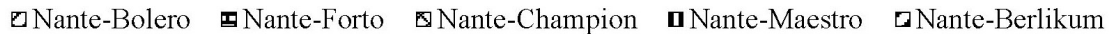

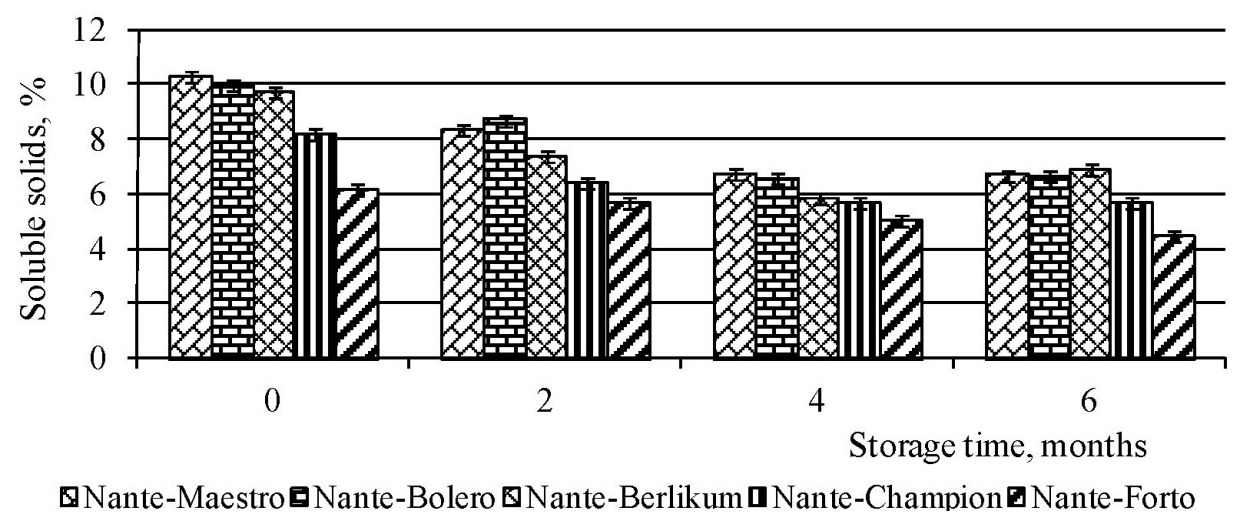

Fig. 2. Dietary fibre content in variety 'Nante' carrot hybrids during storage.
Fig. 3. Soluble solids content in variety 'Nante' carrot hybrids during storage. 
after harvest and degrades steadily during prolonged storage (Ajibola et al., 2009). In the case of vitamin C, the range of observed values was very wide, reflecting the differences known to exist between various cultivars (Matejkova and Petrikova, 2010). In the present study carrot cultivars were autumn carrots; this is strongly evidenced by the higher total vitamin $\mathrm{C}$ content in Nante carrots (Leong and Oey, 2012). Vitamin $C$ acts as an antioxidant in plants and its level is responsive to a variety of environmental or stress factors, for example light, temperature, salt and drought, atmospheric pollutants, metals or herbicides (Smoleń and Sady, 2009; Singh et al., 2012). Literature reports the vitamin $\mathrm{C}$ content in carrot roots as 0.25 to $3.50 \mathrm{mg} 100 \mathrm{~g}^{-1}$ (Singh et al., 2012); $5.70 \mathrm{mg} 100 \mathrm{~g}^{-1}$ (Schwedt, 2007); $4.40-6.50 \mathrm{mg} \cdot 100 \mathrm{~g}^{-1}$ (Fineli, 2011), $7.00 \mathrm{mg} \cdot 100 \mathrm{~g}^{-1}$ (Frede, 2006) and $8.00 \mathrm{mg} \cdot 100 \mathrm{~g}^{-1}$ (Belitz, et al., 2008). These levels are very similar with those of the present study. However, black carrot juice contains high amounts of ascorbic acid: $26.4 \mathrm{mg} \cdot 100 \mathrm{ml}^{-1}$ (Kirca et al., 2007). Researchers from Turkey have reported that such results can be explained by individual hybrid properties, such as chemical composition, and growing conditions (Smoleń and Sady, 2009). Vitamin C is the L-enantiomic form of ascorbic acid, which also encompasses the oxidation product of dehydroascorbic acid with a different oxidizing agent. Oxygen is the most destructive ingredient causing degradation of vitamin $\mathrm{C}$ in carrot. Many chemical reactions contribute to the loss of storage life of vitamin $\mathrm{C}$ and hence chemical deterioration of fruits. The majority of these reactions are enzymatically driven while others are chemical reactions that occur because of senescence (aging) processes (Ajibola et al., 2009). The decrease in vitamin C content with storage duration was attributed to oxidation of ascorbic acid to dehydro-ascorbic acid by the enzyme ascorbic acid oxidase (Jany et al., 2008). Matejkova and Petrikova (2010) reported vitamin $\mathrm{C}$ losses after after 14 days storage at $4{ }^{\circ} \mathrm{C}$ to be by $15 \%$. After 30 days of storage, there was an average decrease in vitamin $\mathrm{C}$ content by $47 \%$.

Researchers from Thailand reported that the average fibre content in fresh carrots is $45.45 \pm 0.41 \mathrm{~g} \cdot 100 \mathrm{~g}^{-1}$ (Chantaro et al., 2008), which is slightly higher than the levels obtained in the present study (Fig. 2). Physiological effects of dietary fibre are greatly dependent on the physicochemical properties of the ingested material, e.g. the water-binding capacity, the molecular weight distribution and the viscosity. Another factor of great nutritional importance is plant cellular structure, which may also play a role in storage stability and sensory characteristics (Nyman and Svanberg, 2002). During storage, toughening takes place, associated with an increase of fibrousness, which devalues the quality of the final product. This quick hardening is mainly located in the basal portions of the spears, and is related to modifications of fibre components by deposition of lignin, cellulose and hemicelluloses (Rodriguez et al., 2006).

In the study by Rashidi, soluble solids content was found to vary even more - from 8.5 to $12.5 \%$, and soluble solid content was similar after four and six-month storage
(Rashidi, 2011). After four- and six-month storage, soluble solid content decreased on average from 1.48 to 1.46 times. A lower content of soluble solid content was observed after storage for all cultivars of carrots in a study conducted in Poland (Gajewski et al., 2010). Soluble solids exert a profound influence on the storage period length, mechanical properties and quality characteristics of fruits and vegetables. It is known that, for example, when fruits are harvested unripe, although physiologically mature, they must be left to ripen (conversion of the stored starch into soluble solids) before consumption (Rakcejeva et al., 2012).

Water uptake phenomena and the resulting moisture content change in food products affect their shelf-life through undesirable modifications of their physical, sensory and microbial qualities. Therefore, it is very important to determine the moisture content of carrots to predict shelf life in general (Rakcejeva et al., 2012). However, there have been recent reports on texture increase in carrot tap roots during the first months of storage (Galindo et al., 2004). In the pectic part of cell walls, the content of uronic acids and their degree of methylation, and hence ionic cross-linking, do not change during storage, and therefore, is a mechanism unlikely to have an effect on storage-induced firmness of carrots (Galindo et al., 2004).

In conclusion, our results demonstrate that higher soluble solid content occurs in non-stored hybrids 'Nante/Berlikum', 'Nante/Maestro' and 'Nante/Bolero': 1.6 times higher compared with hybrid 'Nante/Forto' and 1.2 times higher compared with hybrid 'Nante/Champion'. Higher ascorbic acid content was found in the same hybrids, which was 2.0 times higher than in 'Nante/Forto' and 'Nante/Champion'. Significant differences were not found in dietary fibre content and firmness of the carrots before storage. Significant differences occurred in soluble solid content in hybrid 'Nante/ Berlikum' during six-month storage - the content decreased 2.0 times; however, a non-significant soluble solid content decrease was found for the hybrid 'Nante/Forto'. Changes of hybrid firmness and dietary fibre amount were not significant during storage for four months. A decrease of ascorbic acid content of the analysed carrots hybrids during storage was 3.4 times compared with initial levels.

\section{ACKNOWLEDGEMENTS}

The research and publication were prepared within the framework of the ESF Project "Formation of the Research Group in Food Science”, Contract No 2009/0232/1DP/1.1.1.2.0/09/APIA/VIAA/122.

Publication and dissemination of research results has been made due to the funding of the ERAF Project „Promotion of scientific activities of LLU”, Contract No. 2010/0198/2DP/2.1.1.2.0/10/APIA/VIAA/020.

\section{REFERENCES}

Anonymous (1995). Method 46-12. Crude Protein-Kjeldal Method Boric Acid Modification. Approved Methods of the American Association of cereal Chemists. 9th ed. Vol. 1. St. Paul, Minnesota: AACC Inc. pp., 487-520. 
Ajibola, V. O., Babatunde, O. A., Suleiman, S. (2009). The effect of storage method on the vitamin C content in some tropical fruit juices. Trends Appl. Sci. Res., 4 (2), 79-84.

Belitz, H. D., Grosch, W., Schieberle, P. (2008). Lehrbuch der Lebensmittelchemie, 6. Auflage. Berlin, Heidelberg: Springer. 1118 S.

Brownlee, I. A. (2011). The physiological roles of dietary fibre. Food Hydrocolloids, 25, 238-250.

Chantaro, P., Devahastin, S., Chiewchan, N. (2008). Production of antioxidant high dietary fiber powder from carrot peels. LWT: Food Sci. Technol., 41, 1987-1994.

Chau, C. F., Chen, C. H., Lee, M. H. (2004). Comparison of the characteristics, functional properties, and in vitro hypoglycemic effects of various carrot insoluble fiber-rich fractions. Lebensmittel-Wissenschaft undTechnologie, 37, 155-160.

Eim, V. S., Simal, S., Rossello, C., Femenia, A. (2008). Effects of addition of carrot dietary fibre on the ripening process of a dry fermented sausage (sobrassada). Meat Sci., 80, 173-182.

Emons, H. (2011). Sertificate of Analysis. Dried Carrot. European Reference Material ERM®-BC515, EC-DG JRC-IRMM, 2440, Geel, Belgium. http://www.erm-crm.org. Last accessed 20.07.2012.

Fineli (2011). Finnish Food Composition Database. Carrot. http://www.fineli.fi/food.php?foodid=300\&lang=en. Last accessed 17.07.2012.

Frede, W. (2006). Taschenbuch fūr Lebensmittelchemiker: Lebensmittel, Bedarfsgegenstände, Kosmetika, Futtermittel, 2. Auflage. Berlin, Heidelberg: Springer. $1162 \mathrm{~S}$.

Gajewski, M., Szymczak, P., Radzanowska, J. (2010). Sensory quality of orange, purple and yellow carrots stored under controlled atmosphere. $J$. Notulae Bot. Horti Agrobot. Cluj-Napoca, 38 (3), 169-176.

Galindo, F. G., Bräthen, E., Knutsen, S. H., Sommarin, M., Gekas, V., Sjöholm, I. (2004). Changes in the carrot (Daucus carota L. cv. Nerac) cell wall during storage. Food Res. Int., 37, 225-232.

Gamboa-Santos, J., Soria, A. C., Perez-Mateos, M., Carrasco, J. A., Montilla, A., Villamiel, M. (2012). Vitamin C content and sensorial properties of dehydrated carrots blanched conventionally or by ultrasound. Food Chem., accepted 31 July 2012.

Giannakourou, M. C., Taoukis, P. S. (2003). Kinetic modelling of vitamin C loss in frozen green vegetables under variable storage conditions. Food Chem., 83, 33-41.

Kirca, A., Özkan, M., Cemerošlu, B. (2007). Effects of temperature, solid content and $\mathrm{pH}$ on the stability of black carrot anthocyanins. Food Chem., 101, 212-218.

Jany, M. N. H., Sarker, C., Mazumder, M. A. R., Shikder, M. F. H. (2008). Effect of storage conditions on quality and shelf life of selected winter vegetables. J. Bangladesh Agr. Univ., 6 (2) 391-400.
Leong, S. Y., Oey, I. (2012). Effect of endogenous ascorbic acid oxidase activity and stability on vitamin $\mathrm{C}$ in carrots (Daucus carota subsp. sativus) during thermal treatment. Food Chem., 134, 2075-2085.

Matejkova, J., Petrikova, K. (2010). Variation in content of carotenoids and vitamin C in carrots. Notulae Sci. Biol., 2 (4), 88-91.

Moor, U., Karp, K., Poldma, P., Pae, A. (2005). Cultural systems affect content of anthocyanins and vitamin $\mathrm{C}$ in strawberry fruits. Eur. J. Hort. Sci., 70 (4), 195-201.

Nyman, M. G. L., Svanberg, M. S. J. (2002). Modification of physicochemical properties of dietary fibre in carrots by mono- and divalent cations. Food Chem., 76, 273-280.

Prohens, J., Prohens, J., Nuez, F. (2007). Vegetables II, 1 edn. Valencia, Spain: Springer. 365 p.

Prosky, L. (1990). Collaborative study of a method for soluble and insoluble dietary fiber. Adv. Exp. Med. Biol., 270, 193-203.

Rakcejeva, T., Augspole, I., Dukalska, L., Dimins, F. (2012). Chemical composition of variety 'Nante' hybrid carrots cultivated in Latvia. J. World Acad. Sci. Eng. Technol., pp. 1120-1126.

Rashidi, M. (2011). Modeling of carrot firmness based on water content and total soluble solids of carrot. J. Agr. Biol. Sci., 6 (8), 62-65.

Rastogi, N. K., Nguyen, L. T., Balasubramaniam, V. M. (2008). Effect of pretreatments on carrot texture after thermal and pressure-assisted thermal processing. J. Food Eng., 88, 541-547.

Rawson, A., Tiwari, B. K., Tuohy, M., Brunton, N. (2012). Impact of frozen storage on polyacetylene content, texture and colour in carrots disks. $J$. Food Eng., 108, 563-569.

Rodriguez, R., Jimenez, A., Fernandez-Bolanos, J., Guillen, R., Heredia, A. (2006). Dietary fibre from vegetable products as source of functional ingredients. Trends Food Sci. Technol., 17, 3-15.

Roeck, A. D., Mols, J., Sila, D. N., Duvetter, T.,. Loey, A. V, Hendrickx, M. (2010). Improving the hardness of thermally processed carrots by selective pretreatments. Food Res. Int., 43, 1297-1303.

Schwedt, G. (2007). Chemie für alle Jahreszeiten: Einfache Experimente mit pflanzlichen Naturstoffen. Weinheim: Wiley-VCH. 209 S.

Singh, D. P., Beloy, J., McInerney, J. K., Day, L. (2012). Impact of boron, calcium and genetic factors on vitamin $\mathrm{C}$, carotenoids, phenolic acids, anthocyanins and antioxidant capacity of carrots (Daucus carota). Food Chem., 132, 1161-1170.

Slavin, J. L. (2008). Health implications of dietary fiber. Position of the American Dietetic Association. J. Amer. Dietetic Assoc., 108, 1716-1731.

Smoleń, S., Sady, W. (2009). The effect of various nitrogen fertilization and foliar nutrition regimes on the concentrations of sugars, carotenoids and phenolic compounds in carrot (Daucus carota L.). Sci. Hort., 120 (3), 315-324.

Soria, A. C., Sanz, M. L., Villamiel, M. (2009). Determination of minor carbohydrates in carrot (Daucus carota L.). J. Food Chem., 114, 758-762.

Yen, Y. H., Shih, C. H., Chang, C. H. (2008). Effect of adding ascorbic acid and glucose on the antioxidative properties during storage of dried carrot. Food Chem., 107, 265-272.

Received 14 September 2012

\section{FIZIKĀLI ĶĪMISKO PARAMETRU IZMAIN̦AS 'NANTE' BURKĀNU HIBRĪDOS UZGLABĀŠANAS LAIKĀ TRADICIONĀLOS APSTĀKL,OS}

Pētījuma mērkis bija izvērtēt vēlās burkānu škirnes 'Nante' hibrīdu 'Nante/Forto', 'Nante'/'Čempion', 'Nante/Berlikum', 'Nante/Maestro' un 'Nante/Bolero' fizikāli ķīmiskos rādītājus pēc ražas novākšanas un tradicionālajos uzglabāšanas apstākḷos. Burkāni tika uzglabāti sešus mēnešus $8 \pm 2{ }^{\circ} \mathrm{C}$ temperatūrā, $85 \pm 1 \%$ relatīvā gaisa mitrumā. Kvalitātes parametru izmaiṇas tika noteiktas, izmantojot standarta metodes: šḳīstošā sausna (ar digitālo refraktometru), diētiskās šḳiedrvielas (AOAC 985.29), vitamīns C (jodometrijas metode) un stingrība (TA.XT.plus Texture Analyser). Pētījumos analizēto burkānu hibrīdos vitamīna C saturs uzglabāšanas laikā samazinājās 3,4 reizes, salīdzinot ar sākotnējiem rādītājiem. Būtiskas atškirības novērojām šḳīstošās sausnas saturā vēlo burkānu škiinnes 'Nante/Berlikum' hibrīdos. Pēc sešu mēnešu uzglabāšanas tas samazinājās 2,0 reizes. Stingrības un diētiskās šḳiedrvielas saturā būtiskas izmaiņas burkānu hibrīdos uzglabāšanas laikā līdz četriem mēnešiem netika konstatētas. Pētījumā iegūtie rezultāti dod pārskatu par Latvijā audzētu burkānu fizikāli kịmisko sastāvu un to piemērotību minimālās apstrādes produktu ražošanai. 